\title{
Incidence of hepatitis $C$ virus infection in Italian patients with idiopathic pulmonary fibrosis
}

Riccardo Meliconi, Pietro Andreone, Luca Fasano, Silvia Galli, Angela Pacilli, Rita Miniero, Mario Fabbri, Laura Solforosi, Mauro Bernardi

\begin{abstract}
Background - A viral cause of idiopathic pulmonary fibrosis (IPF) was recently suggested by a Japanese study in which a high prevalence of anti-hepatitis $\mathrm{C}$ virus (HCV) antibodies was detected. A subsequent British study failed to confirm these results.

Methods - Antibodies to HCV were evaluated in 60 patients with IPF, 130 patients with non-interstitial lung disease, and in 4614 blood donors. HCV-RNA and HCV genotypes were evaluated in the anti-HCV positive patients with IPF. Anti-HCV antibodies were evaluated by ELISA and confirmed by recombinant immunoblotting assay (RIBA). HCV-RNA and genotypes were detected by reverse transcriptase polymerase chain reaction (PCR).

Results - Eight patients with IPF had anti-HCV antibodies detected by ELISA $(13.3 \%)$. In the blood donor control group the prevalence of $\mathrm{HCV}$ antibodies was lower $(0 \cdot 3 \%)$. In patients with non-interstitial lung disease HCV antibody prevalence was $6 \cdot 1 \%$. In all eight patients with IPF found to be anti-HCV positive by ELISA, HCV antibodies were also detected by RIBA. Furthermore, all were HCVRNA positive by PCR assay. HCV genotypes were identified in four of these eight patients. In all four genotype II was present and in two it was associated with genotype III and/or genotype IV. In the remaining four cases the genotype was not identified. Conclusion - Italian patients with IPF show an increased prevalence $(\sim 13 \%)$ of HCV infection and viral replication, but the prevalence of anti-HCV antibodies does not differ from other lung diseases. (Thorax 1996;51:315-317)
\end{abstract}

Keywords: idiopathic pulmonary fibrosis, hepatitis C virus, genotypes.

Idiopathic pulmonary fibrosis (IPF) is a chronic disease of the lung interstitium. Two different histological patterns may be observed either simultaneously or consecutively - a desquamative or cellular pattern and an interstitial or fibrotic one. ${ }^{1}$ In recent years major advances have been made in understanding the pathogenesis of the inflammatory and fibrotic mechanisms at work in IPF ${ }^{1}$ but its aetiology remains unresolved. A viral trigger to the immunopathogenic mechanism has long been sought.
Recently Prieto et $a l^{2}$ reported the efficacy of the inhaled antiviral agent ribavirin in a patient with IPF, but Agusti et al found no benefit with this therapy. ${ }^{3}$ Ueda $e t ~ a l^{4}$ found an increased prevalence of antibodies to hepatitis $C$ virus (HCV) in Japanese patients with IPF, but Irving et $a l^{5}$ failed to confirm these findings in a British series of patients with IPF. We have performed a retrospective study on the prevalence of $\mathrm{HCV}$ infection in a series of Italian patients with IPF.

\section{Methods}

Serum samples were obtained from 60 patients with IPF (43 men) of mean age 61 years (range 30-82). The diagnosis was made on clinical, radiological, physiological, and histological grounds. The criteria used included: history of dyspnoea and cough, fine crackles on physical examination, compatible findings on the chest radiograph (diffuse basal reticulonodular shadowing), restrictive pattern of pulmonary function, and a reduced diffusing capacity. In addition, no associated connective tissue disease was present nor was there a history of occupational exposure or hypersensitivity. Histological confirmation was obtained in $70 \%$ of cases (transbronchial biopsy in $60 \%$ and open lung biopsy in $10 \%$ ). In the remaining patients high resolution computed tomographic scanning of the lungs (HRCT) was performed. ${ }^{6}$

All but three patients had been seen consecutively at the Chest Department of our University Hospital during the last 10 years. Serum samples were obtained on first admission and stored at $-70^{\circ} \mathrm{C}$. Control subjects consisted of 4614 healthy blood donors who were screened for anti-HCV antibodies by the Blood Transfusion Service at our hospital during 1992. In addition, 130 patients ( 84 men) of mean age 63 years (range $21-85$ ) consecutively admitted during 1994 for non-interstitial lung diseases (chronic obstructive lung disease 93, neuromuscular chest wall diseases 13, pulmonary vascular diseases 11 , bronchiectasis 7 , chronic pleural diseases 4 , tuberculosis 2) were also screened for anti-HCV antibodies. The $\mathrm{HCV}$ results in these patients were collected by checking their clinical records.

Anti-HCV antibodies were detected by the second generation immunoassays ELISA (Ortho Diagnostic System, Raritan, New Jersey, USA) and RIBA (Chiron Corporation, Emerville, California, USA). Viral replication was evaluated by reverse transcriptase (RT)/ PCR using "nested" PCR primers following 
Clinical and virological data from the eight anti-HCV positive patients with idiopathic pulmonary fibrosis

\begin{tabular}{|c|c|c|c|c|c|c|c|c|c|c|c|c|}
\hline \multirow[t]{2}{*}{ Patients } & \multirow[t]{2}{*}{ Sex } & \multirow{2}{*}{$\begin{array}{l}\text { Age } \\
\text { (years) }\end{array}$} & \multirow{2}{*}{$\begin{array}{l}\text { Disease } \\
\text { duration } \\
\text { (months) }\end{array}$} & \multirow[t]{2}{*}{$T$} & \multirow{2}{*}{$\begin{array}{l}\text { Abnormal } \\
\text { liver function } \\
\text { tests* }\end{array}$} & \multirow{2}{*}{$\begin{array}{l}\text { Anti-HCV } \\
\text { ELISA } \\
\text { (OD) }\end{array}$} & \multicolumn{4}{|c|}{ Anti-HCV RIBA } & \multirow[t]{2}{*}{$H C V-R N A$} & \multirow{2}{*}{$\begin{array}{l}\mathrm{HCV} \\
\text { genotype }\end{array}$} \\
\hline & & & & & & & 5.1.1. & $c 100.3$ & $c 33 . c$ & $c 22.3$ & & \\
\hline $\begin{array}{l}1 \\
2 \\
3 \\
4^{* *} \\
5 \\
6 \\
7 \\
8\end{array}$ & $\begin{array}{l}M \\
M \\
M \\
M \\
F \\
F \\
M \\
F\end{array}$ & $\begin{array}{l}57 \\
61 \\
80 \\
68 \\
62 \\
64 \\
50 \\
54\end{array}$ & $\begin{array}{l}10 \\
10 \\
\text { NA } \\
24 \\
33 \\
27 \\
18 \\
36\end{array}$ & $\begin{array}{l}\text { Yes } \\
\text { No } \\
\text { No } \\
\text { No } \\
\text { No } \\
\text { Yes } \\
\text { Yes } \\
\text { Yes }\end{array}$ & $\begin{array}{l}\text { No } \\
\text { Yes } \\
\text { Yes } \\
\text { Yes } \\
\text { No } \\
\text { No } \\
\text { Yes } \\
\text { Yes }\end{array}$ & $\begin{array}{l}>3.0 \\
>3.0 \\
>3.0 \\
>3.0 \\
>3.0 \\
>3.0 \\
>3.0 \\
>3.0\end{array}$ & $\begin{array}{l}+ \\
++++ \\
+ \\
++++ \\
+ \\
- \\
-\end{array}$ & $\begin{array}{l}- \\
++++ \\
+ \\
++++ \\
+++ \\
- \\
+++ \\
-\end{array}$ & $\begin{array}{l}+ \\
++++ \\
++++ \\
++++ \\
++++ \\
+++ \\
++++ \\
++++\end{array}$ & $\begin{array}{l}+++++ \\
+++++ \\
+++++ \\
++++ \\
++++ \\
++++ \\
- \\
++++\end{array}$ & $\begin{array}{l}+ \\
+ \\
+ \\
+ \\
+ \\
+ \\
+ \\
+\end{array}$ & $\begin{array}{l}\text { II, III, IV } \\
\text { Ind } \\
\text { II, IV } \\
\text { II } \\
\text { II } \\
\text { Ind } \\
\text { Ind } \\
\text { Ind }\end{array}$ \\
\hline
\end{tabular}

* At the time of virological investigations

** Patient with biopsy proven chronic active hepatitis.

$\mathrm{T}=$ immunosuppressive treatment at the time of virological investigations; NA=not available; $\mathrm{OD}=$ optical density; Ind =indeterminate.

the method of Ravaggi and coworkers ${ }^{7}$ with a minor modification: before the PCR procedure serum samples were subjected to solid phase RNA extraction with Exdna Biomek 100 (Beckman Analytical, Milan, Italy).

$\mathrm{HCV}$ genotypes were evaluated using the method described by Okamoto et $a l^{8}$ for genotypes I, II, IV, V and the method described by Silini et $a l^{9}$ for genotype III.

Major risk factors for $\mathrm{HCV}$ infection included multiple transfusions and intravenous drug abuse. Minor risk factors were tattooing, working in health care institutions, living in institutions and surgical procedures.

The prevalence of anti-HCV antibodies in the IPF and control groups was compared using the $\chi^{2}$ test.

\section{Results}

Eight of the 60 patients with IPF were positive for anti-HCV as detected by ELISA (13.3\%), a significantly higher prevalence than that obtained in the blood donor group (14/4614, $0 \cdot 3 \%, \mathrm{p}<0 \cdot 0001)$. Anti-HCV antibodies were found in eight of 130 patients $(6 \cdot 1 \%)$ with noninterstitial lung disease. No clustering of the anti-HCV positive patients in a single diagnostic group was observed. This prevalence is significantly higher than that of blood donors $(\mathrm{p}<0.0001)$ but is not significantly different from that of the patients with IPF. While no risk factor for $\mathrm{HCV}$ infection was present in patients with IPF, five of these eight anti-HCV positive patients had major risk factors (four had received multiple transfusions and one was an intravenous drug abuser) and two had a history of surgical treatment.

All eight anti-HCV positive patients with IPF were also positive for two or more antigens by the RIBA (table), and all had circulating HCVRNA detected by RT/PCR.

HCV genotypes were identified in four patients. All were type II positive and two were also infected with genotypes III and IV. Genotypes were unidentified in the remaining four cases (table).

At the time of the viral investigations five of the eight patients had mild biochemical signs of liver disease which fluctuated both before and after the viral studies. Three other patients did not show elevated transaminase values either before or after HCV-RNA detection. Liver biopsy was performed in only one patient and showed chronic active hepatitis.

\section{Discussion}

The determination of anti-HCV antibodies in the serum samples of our Italian patients with IPF confirms the results obtained in Japan. ${ }^{3}$ Furthermore, all anti-HCV positive patients were also positive for $\mathrm{HCV}-\mathrm{RNA}$, indicating active $\mathrm{HCV}$ replication in $13.3 \%$ of patients with IPF. Irving et al did not find a significant increase in anti-HCV antibodies in their series and suggested either geographical differences in the aetiology of IPF or false positive tests in the Japanese study. Possible false positives were ascribed to the poor specificity of first generation screening ELISA for anti-HCV and the interference of high levels of IgG in patients with IPF. We used a second generation ELISA and the results obtained with RT/PCR stressed the specificity of our anti-HCV antibody tests. There is a discrepancy between our results and the negative British study although the two patient populations appeared to be clinically similar. Geographical difference may be a factor. Indeed, the prevalence of HCV infection is high in Japan and Mediterranean countries and low in Northern Europe. The prevalence of anti-HCV antibodies in our series was higher than in the blood donor control group, but these subjects do not represent the most appropriate control group as they were younger and had a selection bias. People who volunteer as blood donors are generally not at risk for hepatitis viruses; however, the prevalence of $\mathrm{HCV}$ has recently been documented in the general population of Northern Italy at $3.2 \%$ which is lower than that found in patients with IPF. $^{10}$

The high prevalence of $\mathrm{HCV}$ infection found in patients with IPF is similar to that in the group with other lung diseases. It should be noted that we did not determine HCV-RNA in this group and, among the eight positive cases, five had major and two had minor risk factors for hepatitis $C$ whereas none of the HCV positive patients with IPF had risk factors. A common feature in the two groups (IPF and other lung diseases) is a history of multiple hospital admissions which could be an additional risk factor for $\mathrm{HCV}$ infection. ${ }^{11}$

The study of HCV genotypes provided three points. Firstly, in four of eight patients the genotype was not identified, perhaps due to as yet unclassified genotypes, but the prevalence of indeterminate genotypes is very low in patients who have not had multiple transfusions ${ }^{12}$. Secondly, all four patients in whom 
genotypes were identified had genotype II alone or in combination with other types, and the high frequency of type II genotype is in keeping with the prevalence in Italy. ${ }^{13}$ Thus, HCV infection in patients with IPF is not associated with specific genotypes. Thirdly, in two patients a combination of two and three genotypes was present, a rare association in a single patient and almost exclusively confined to cases who have received multiple transfusions. ${ }^{12}$

This work was in part supported by grant "ex-60\%" from Ministero dell'Università e della Ricerca Scientifica e Tecnologica (MURST) to Riccardo Meliconi.

1 King TE. Idiopathic pulmonary fibrosis. In: Schwarz MI, King TE, eds. Interstitial lung disease. St Louis: Mosby King TE, eds. Interstitial lun

2 Prieto J, Sandro B, Beloqui O. Ribavirin in desquamative interstitial pneumonia. Chest 1988;93:446-7.

3 Agusti C, Xaubet A, Ballester E, Alarcòn A, Picado C. Aerosolized ribavirin in patients with advanced cryptogenic fibrosing alveolitis: a pilot study. Thorax 1993;48 68-9.

4 Ueda T, Ohfa K, Suzuki N, Yamaguchi M, Hirai K, Hosiuchi $\mathrm{T}$, et al. Idiopathic pulmonary fibrosis and high prevalence of serum antibodies to hepatitis $\mathrm{C}$ virus. $\mathrm{Am}$ Rev Respir Dis 1992;146:266-8.

5 Irving WL, Day S, Johnston DA. Idiopathic pulmonary fibrosis and hepatitis C virus infection. Am Rev Respir Dis fibrosis and hepatit

6 Webb Wr, Müller WL, Naldich DP. High resolution CT of the lung. New York: Raven Press, 1992:57-9.

7 Ravaggi A, Primi D, Cariani E. Direct PCR amplification of HCV RNA from human serum. PCR Methods Appl 1993;1:291-2.

8 Okamoto H, Kurai K, Okada S-I, Yamamoto K, Lizuka $\mathrm{H}$ Tanaka $\mathrm{T}$, et al. Full-length sequence of a hepatitis $\mathrm{C}$ virus genome having poor homology to reported isolates: comparative study of four distinct genotypes. Virology 1992;188:331-41.

9 Silini E, Bono F, Cerino A, Piazza V, Solcia E, Mondelli MU. Virological features of hepatitis C virus infection in hemodialysis patients. F Clin Microbiol 1993;31:2913-7.

10 Bellentani S, Tíribelli C, Saccoccio G, Sodde M, Fratti N, De Martin C, et al. Prevalence of chronic liver disease in the general population of Northern Italy: the Dionysos study. Hepatology 1994;20:1442-9.

11 Baraldini M, Miglio F, Pirillo L, Cursaro C, Meliconi R, Stefanini GF, et al. Hepatitis B virus markers in hematologic patients: relation to transfusion treatment and hospitalization. Vox Sang 1983;45:112-20.

12 Ichimura H, Tamura I, Kurimura O, Koda T, Mizui M, Tsuchie $\mathrm{H}$, et al. Hepatitis $\mathrm{C}$ virus genotypes, reactivity to recombinant immunoblotting assay 2 antigens and liver disease. $\mathcal{F}$ Med Virol 1994;43:212-5.

13 Dusheiko G, Schmilovitz-Weiss H, Brown D, McOmish F, Yap PL, Sherlock S, et al. Hepatitis C virus genotypes: an investigation of type-specific differences in geographic origin and disease. Hepatology 1994;19:13-8.

\section{Use of tracheal auscultation for the assessment of bronchial responsiveness in asthmatic children}

\author{
Aline B Sprikkelman, Marion H Grol, Marlies S Lourens, Jorrit Gerritsen, \\ Hugo S A Heymans, Wim M C van Aalderen
}

respiratory rate, and/or prolonged expiration. In two subjects altered lung sounds were detectable one dose step before $\mathbf{P D}_{20}$ was reached. In three cases in whom no fall in $\mathrm{FEV}_{1}$ occurred, no change in lung sounds could be detected at the highest methacholine dose.

Conclusion - Changes in lung sounds correspond well with a $20 \%$ fall in $\mathrm{FEV}_{1}$ after methacholine challenge. Wheeze is an insensitive indicator for assessing bronchial responsiveness. Cough, increase in respiratory rate, and prolonged expiration occurs more frequently.

(Thorax 1996;51:317-319)

Keywords: bronchial responsiveness, lung sounds, children

Measurement of bronchial responsiveness to methacholine has been useful in the diagnosis, assessment of severity, and follow up of asthma, but some children are not able to perform spirometric tests reliably. ${ }^{1}$ A method based on detecting audible wheeze over the trachea and requiring passive cooperation only has been described for bronchial challenge with methacholine in children. ${ }^{2}$ In older children a close correlation has been observed between the $20 \%$ fall in forced expiratory volume in one second expiration were assessed. choline dose causing a fall in $F E V_{1}$ of $20 \%$ or more $\left(\mathbf{P D}_{20}\right)$ was detected in 12 children wheeze and in eight by cough, increased
\end{abstract}

